\title{
Colmatación de poros en morteros de cemento por tratamientos químicos y desecación a distintintas temperaturas
}

\author{
The refilling of pores in cement mortars \\ treated by chemicals and desiccation \\ at different temperatures
}

IGNACIO MENENDEZ PAZOS, ICCET/CSIC
FRANCISCO HERNÁNDEZ, ETSICCPM
FERNANDO TRIVIÑO VÁZQUEZ, ICCET/CSIC FERNANDO TRIVIÑO VÁZQUEZ, ICCET/CSIC
ESPANAA

Fecha de recepción: 11-VI-92

\section{$R E S U M E N$}

Basados en los principios del producto de solubilidad, se rellerian los poros de las probetas de mortero de cemento por impregnación con dos sales que forman otra insoluble.

Se determina el número de tratamientos a realizar y las temperaturas de secado más idóneas en cada caso.

Se emplean sales cálcicas como impregnantes, y urea, oxalato sódico y azúcar como precipitantes, obteniéndose en cada caso las correspondientes ocupaciones de poros que dependen, por lo general, del número de tratamientos $y$, en particular, de la temperatura de secado.

\begin{abstract}
$S \cup M M A R Y$
Bases under the law of solubility product, the pores of the cement mortar are refilled by impregnation with two salts that form another insoluble salt.
\end{abstract}

The number of treatments to be underdone and the drying temperatures more suitable in each case.

The calcium salts like impregnants and urea sodium oxalate and sugar like precipitates are employed, obtained in each case the corresponding pores are occupied, which depends generally on the number of treatments and in particular the drier temperature.

\section{INTRODUCCIÓN}

La durabilidad, en los materiales de construcción, está íntimamente relacionada con la materia prima utilizada, fabricación, acabado y posterior utilización del material resultante (1).

La influencia del ataque por los agentes atmosféricos de los materiales de construcción se potencia con la comunicación, desde el interior de los mismos, a través de los poros y conductos capilares con el medio que les rodea, siendo éste el camino que conduce a su destrucción $(2,3,4$ y 5$)$.

\section{INTRODUCTION}

The durability of the building materials are closely related with the raw material employed, manufacturing, finished and the last application of the material finished.

The influence of the attack by atmospheric agents of the building materials, is increased with the communication through the pores and capillary tubes from the inside to the environment, being this, the way that it contributes to its destruction (2, 3, 4 and 5). 
La idea de rellenar los poros y cerrar los conductos capilares para evitar la comunicación del interior del material con el medio que le rodea ha llevado a estudiar, partiendo de sales solubles cálcicas, la formación de productos en forma de precipitados insolubles en el interior del material, colmatando los poros abiertos y conductos capilares, para lo cual se ha utilizado urea, oxalato sódico y azúcar.

En general, todo proceso que conduzca a que los materiales de construcción sean más impermeables es de gran interés, motivo por el cual se ha indicado el estudio de este inédito método de impermeabilización de materiales de construcción. Al hablar de impermeabilizar nos estamos refiriendo fundamentalmente al agua.

Por otra parte, es de gran interés hacer el estudio de los tratamientos del mortero de cemento con desecación posterior de los mismos, a distintas temperaturas, dada la influencia que ésta tienen en los procesos físico-químicos.

\section{CONSIDERACIONES PREVIAS}

En el caso que nos ocupa el material es mortero de cemento, sobre el cual puede actuar el agua negativamente de múltiples formas (6 y 7 ):

a) Durante su fabricación el exceso de la misma da lugar a un incremento de la porosidad y red capilar, y un descenso en las resistencias mecánicas.

b) Durante el período de endurecimiento del material la carencia de agua conduce a un mal curado del mismo y, por lo tanto, se producen fisuraciones $y$ retracciones.

c) La elevada absorción de agua, como consecuencia de una alta porosidad abierta y capilaridad, conduce a que el material sea más heladizo y menos durable. Se producen corrosiones en las armaduras al actuar el mortero como conductor electrolítico, fisuraciones debidas a cristalizaciones o a transformaciones expansivas.

De todo ello se concluye que el agua, como material disolvente, actúa física y químicamente de manera irreversible sobre los materiales $y$, en particular, sobre los morteros disminuyendo su durabilidad.

La oclusión de los poros mediante precipitados insolubles puede paliar en gran medida el deterioro del material $y$, como consecuencia, aumentar su durabilidad $(8,9,10,11,12$, 13,14 y 15).
The idea of refilling and closing the pores and capillary tubes, to avoid the contact between the inside of the material with the environment, has brought upon the study, starting from the formation products in the form of insoluble precipitates inside the materials depart from solubles calcium salts, refilling the open pores and capillary tubes, for this purpose urea, sodium oxalate and sugar are used.

On the whole it is most interesting that all processes that lead to the construction materials should be impermeability, this is the reason we have started this particular study of the impermeability of the construction materials. When we talk about impermeability we are basically referring to water.

On the other hand, it is very interesting to study the treatments of mortar of cement, with a later desiccation of them at different temperatures, due to the influence that this desiccation has in physical-chemical processes.

\section{PRELIMINARY CONSIDERATIONS}

In the case we are referring to is the material of mortar cement, upon which water can act negatively in many ways, (6 and 7):

a) During the manufacturing, an excess of water could result a increase porosity and capillary net and the decrease in the mechanical strength.

b) During the period of hardening of the material the lack of water could result in poor curing and this produces cracks and shrinkage.

c) The high absorption of water, as the consequence high open porosity and capillarity, results in the material been more frosted and less lasting. Corrosion on the armature on produce when the mortar act as electrolytic conductor, cracking due to the crystallization or expansion transformations.

From on these we come to the conclusion that water use as solvent material acts physically and chemically or irreversible way on the materials and particullary on mortars lowering their durability.

The oclusion of the pores by insoluble precipitates can help a great deal the deterioration of the material and this way increase their durability $(8$, $9,10,11,12,13,14$ and 15). 


\section{PARTE EXPERIMENTAL: TRATAMIENTO $Y$ DESECACIÓN A DISTINTAS TEMPERATURAS DE LAS PROBETAS DE MORTERO DE CEMENTO}

Las probetas de mortero de cemento fabricadas con la dosificación en peso $1: 3$, con una relación agua/cemento de 0,65 - utilizando como árido arena de río de tamaño comprendido entre 0 y $5 \mathrm{~mm}$ - y siendo el cemento utilizado portland: tipo $1 / 45 \mathrm{~A}$, fueron desmoldadas al día siguiente de su fabricación y marcadas con los números: 13/14/15/16/17/18/19/20/21/22/23/24/25 y 26 , pasando posteriormente a una cámara de curado permaneciendo independientemente sumergidas en agua durante 28 días a la temperatura de $21 \pm 1^{\circ} \mathrm{C}$, finalizando dicho período de tiempo se deteminaron sus masas. A continuación dichas probetas se desecaron a $20^{\circ} / 30^{\circ} / 40^{\circ} / 50^{\circ} / 60^{\circ} / 70^{\circ}$ y $80^{\circ}$ respectivamente. Sus velocidades de desecación se encuentran reflejadas en la figura 1.

Pérdidas de humedad de las probetas en función del tiempo al desecarse a las distintas temperaturas citadas.

\section{EXPERIMENTAL PART: TREATMENT AND DESICCATION OF THE DIFFERENT TEMPERATURES OF THE MORTAR OF CEMENT TEST PIECES}

The mortar of cement test pieces manufactured with filling in weight $1: 3$, with a rate of water/cement 0,65 , using like as aggregate river sand size between 0 and $5 \mathrm{~mm}$, using Portland cement: type 1/45 $A$, manufacture and marked with the numbers: $13 / 14 / 15 / 16 / 17 / 18 / 19 / 20 /$ /21/22/23/24/25 and 26; being put after into a curing chamber where they were immersed independently in water 28 days at the temperature of $21 \pm 1^{\circ} \mathrm{C}$, afther this period of time finished, the bulk were determined. Inmediately afther such test pieces were desicated to $20^{\circ} / 30^{\circ} / 40^{\circ} / 50^{\circ} / 60^{\circ} / 70^{\circ}$ and $80^{\circ} \mathrm{C}$. Their rate of desiccation is reflected in the Fig. 1.

Humidity loses of the test pieces in relation with time to desiccation of different mentioned temperatures.

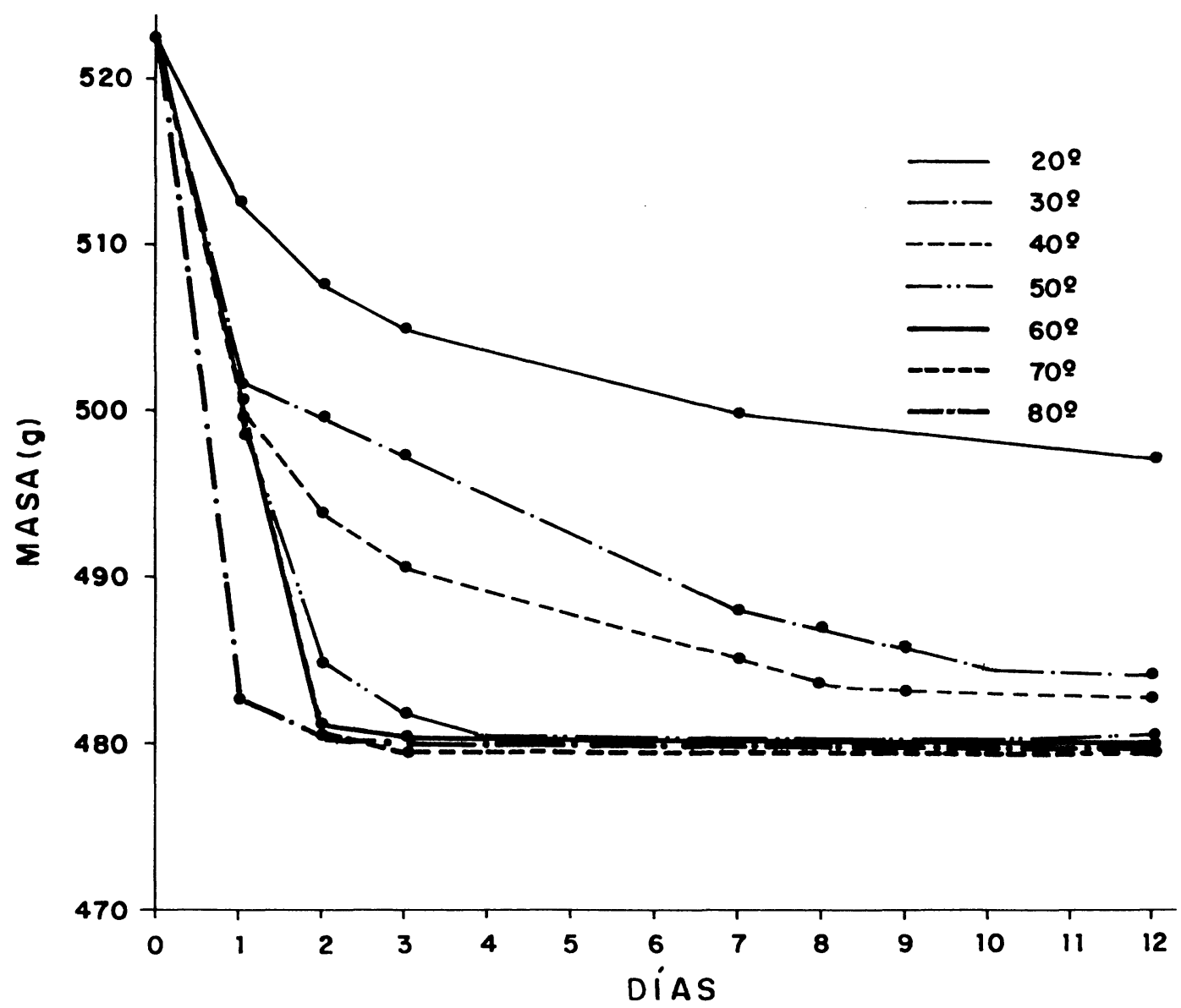

Fig. 1 
A continuación las probetas se saturaron de agua y desecaron a las diversas temperaturas hasta constancia en la pesada, sumergiéndose en las disoluciones saturadas de los distintos productos químicos:

- Las probetas números: $13,15,17,19$ 2123 y 25 con nitrato cálcico durante 24 horas y desecándose posteriormente a la temperatura prefijada hasta constancia en la pesada. El tiempo de desecación dependió de la temperatura, habiendo sido éste como máximo de 15 días. Las anteriores probetas, una vez desecadas, se sumergieron durante 24 horas en sendas disoluciones saturadas de: urea, oxalato sódico y azúcar.

- Las probetas números 15 y 21 en urea (U), desecándose a $30^{\circ}$ y $60^{\circ}$ respectivamente durante 9 y 7 días (Fig. 2).

- Las probetas números 17 y 23 en oxalato sódico (O), desecándose a $40^{\circ}$ y $70^{\circ} \mathrm{C}$ respectivamente durante 7 y 6 días (Fig. 3).

- Las probetas números 19 y 25 en azúcar (A), desecándose a $50^{\circ}$ y $80^{\circ} \mathrm{C}$ durante 7 y 6 días respectivamente (Fig. 4).

- Las probetas números 15, 17, 19, 21, 23 y 25 se volvieron a sumergir en disoluciones saturadas de nitrato cálcico durante una hora, desecándose a continuación a $30^{\circ}, 40^{\circ}, 50^{\circ}$, $60^{\circ}, 70^{\circ}$ y $80^{\circ}$ respectivamente durante 6 a 8 dias. Se repitió el tratamiento con urea, oxalato sódico y azúcar durante una hora, desecándose a continuación en un tiempo máximo de 10 días, según temperatura (Fig. 5).

Finalizados los tratamientos de las probetas se determinó el volumen de poros y el volumen rellenado en cada caso de ellos, así como los incrementos másicos de las probetas desecadas al saturarlas en agua, o en las distintas disoluciones salinas, y el porcentaje de poros rellenados dado por la expresión:

$$
A b(\%)=\left(1-\delta / \delta_{1}\right) \cdot 100
$$

donde $\mathrm{i}=1,2,3 \ldots$ según tratamiento, Msa masa saturada de agua, Md masa desecada, $\delta=$ Msa - Md.

Las masas de las probetas desecadas, así como sus correspondientes incrementos en los tratamientos y sus respectivos porcentajes de poros rellenados, se pueden ver en las figuras 6 , 7 y 8.
Following up the test pieces saturated in water and desiccated at different temperatures until weight constant inmers in the saturations solutions of the different chemical products:

- The test pieces numbers 13, 15, 17, 19, 21, 23 and 25, with calcium nitrate during 24 hours and been desiccated afterwards and at already fix temperature until constant weight. The time of desiccation depends on the temperature, as this has been a maximum of 15 days. The previous test pieces once desiccated are immersed during 24 hours in different solutions saturated in: Urea, sodium oxalate and sugar.

- The numbers 15 and 21, in urea (U), desiccated to $30^{\circ}$ and $60^{\circ} \mathrm{C}$ respectively during 9 and 7 days. Fig. 2.

- The numbers 17 and 23, in sodium oxalate (O), desiccated to $40^{\circ}$ and $70^{\circ} \mathrm{C}$ respectively during 7 and 6 days. Fig. 3.

- The test pieces numbers 19 and 25 in sugar (S), desiccated to $50^{\circ} \mathrm{C}$ and $80^{\circ} \mathrm{C}$ respectively during 7 and 6 days. Fig. 4.

- The test numbers 15, 17, 19, 21, 23 and 25, they were immersed in a disolution saturated with calcium nitrate during an hour, desiccated inmediately at $30^{\circ}, 40^{\circ}, 50^{\circ}, 60^{\circ}, 70^{\circ}$ and $80^{\circ} \mathrm{C}$ respectively during 6 to 8 days. The treatment was repeated with urea, sodium oxalate and sugar during an hour, desiccating in a maximum time of 10 days according to the temperature. Fig. 5.

Once the treatments of the test pieces were finished, the volume of the pores was looked for refilling volumen in each one for them as also the increase bulks of the desiccate test pieces when they were saturated in water in the different saline solutions and percentage of pores refilled given by the expression:

$$
A b(\%)=\left(1-\delta / \delta_{1}\right) \cdot 100
$$

where $i=1,2,3$ according to the treatment Msa = bulk saturated of water, Md = bulk desiccated, $\delta=$ Msa - Md.

The bulk of the desiccated test pieces, as also the corresponding increases in their treatments and their respective percentages of their refilled pores, can be seen on the figures 6,7 and 8 . 


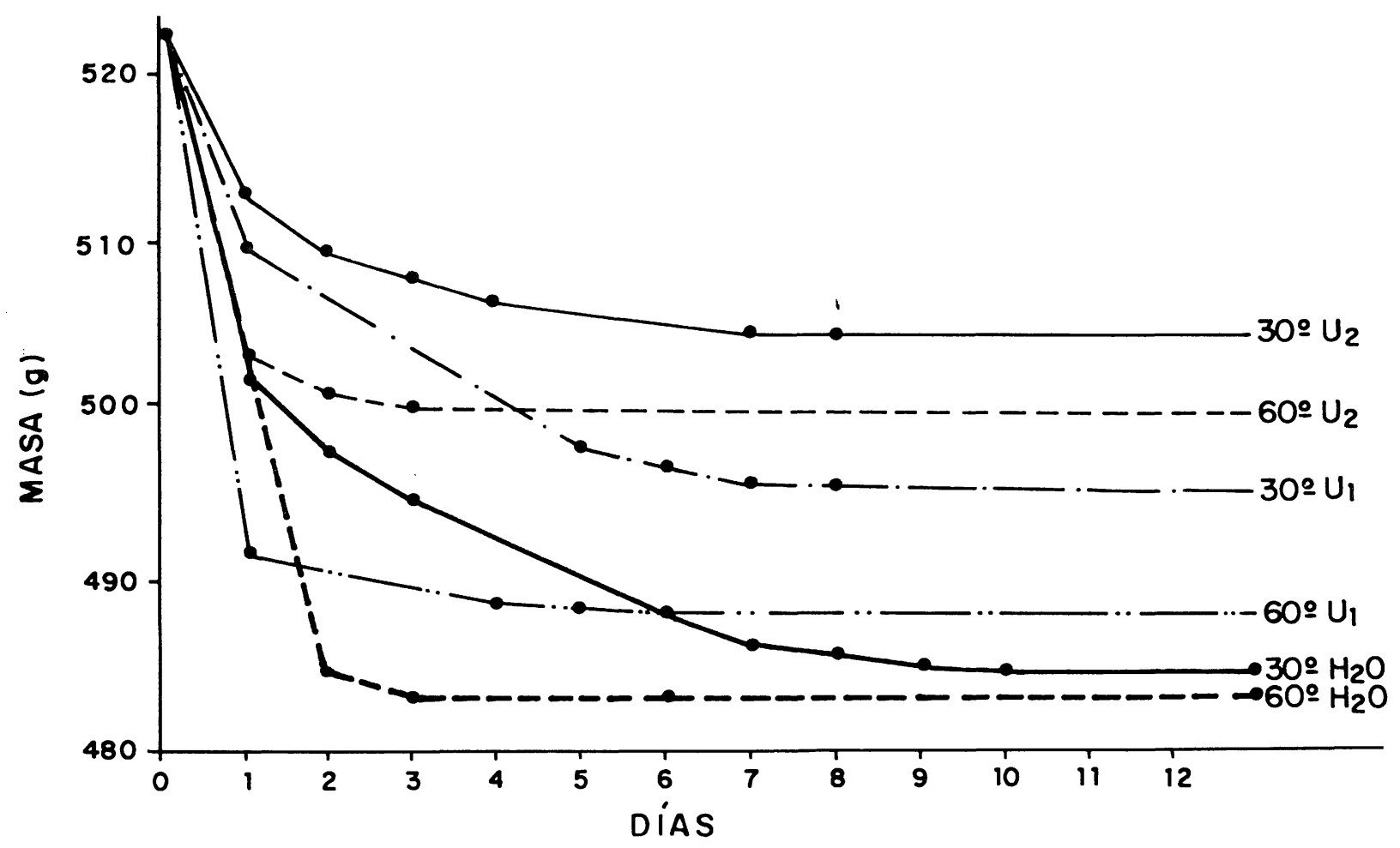

Fig. 2

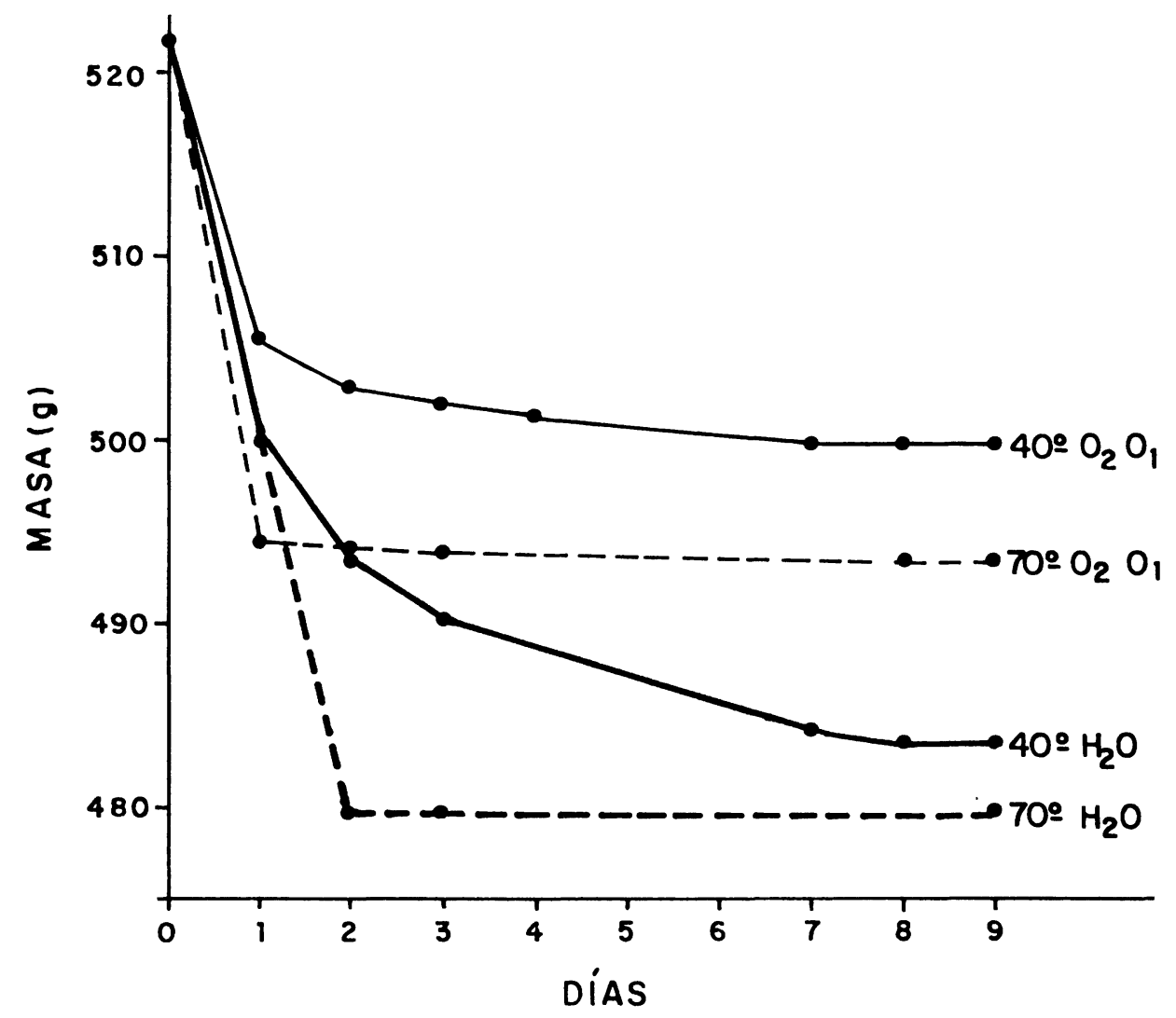

Fig. 3 


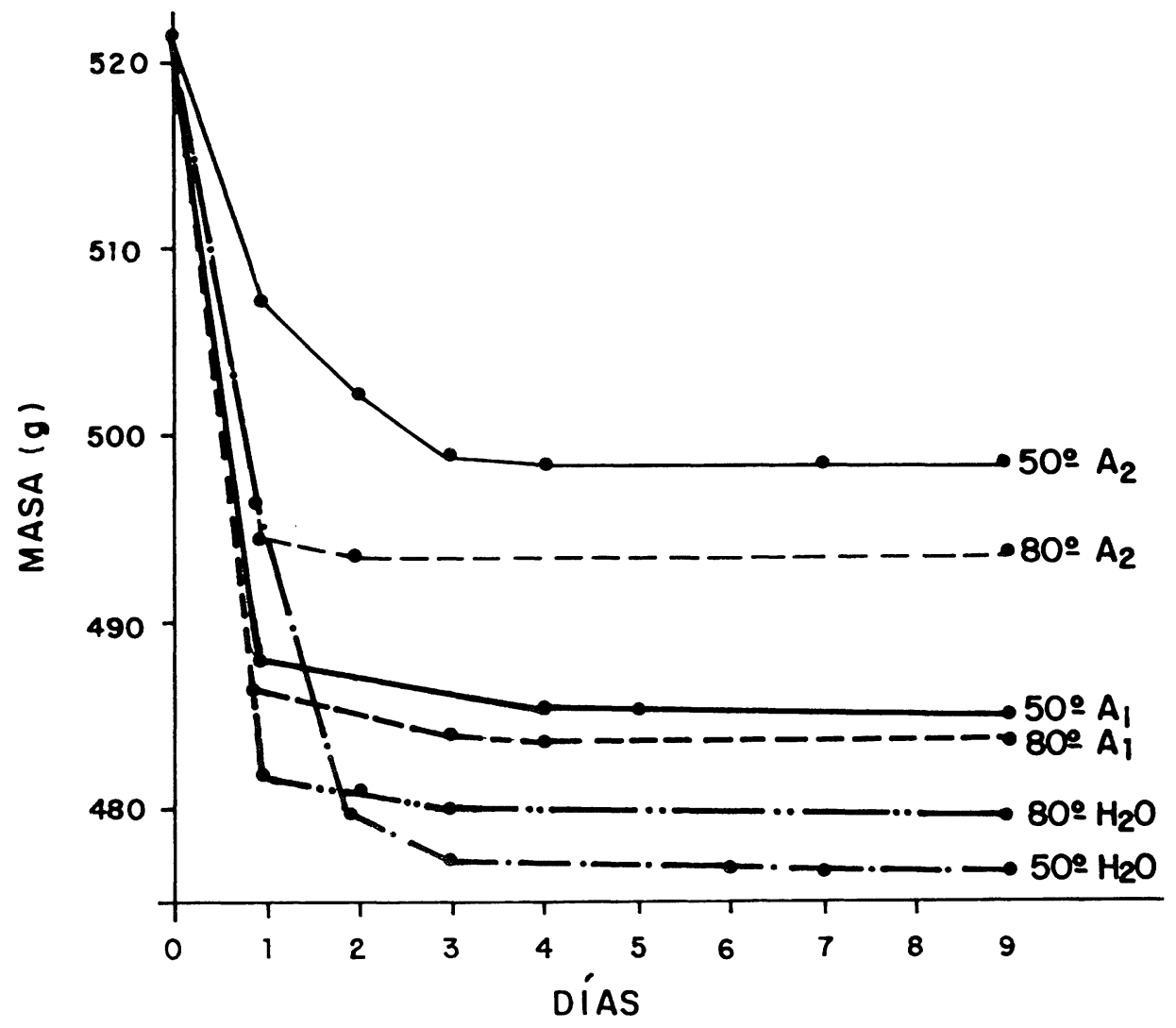

Fig. 4

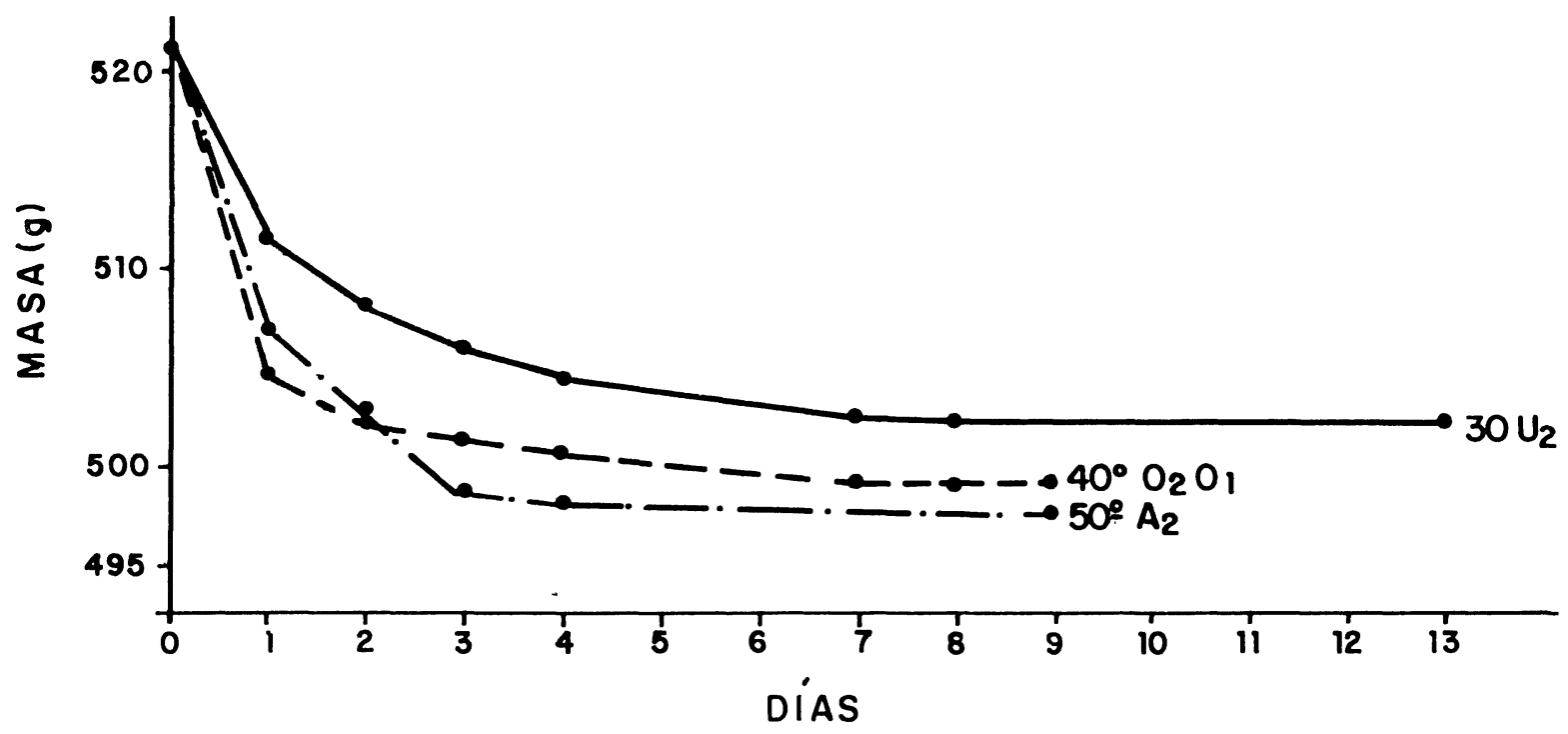

Fig. 5 


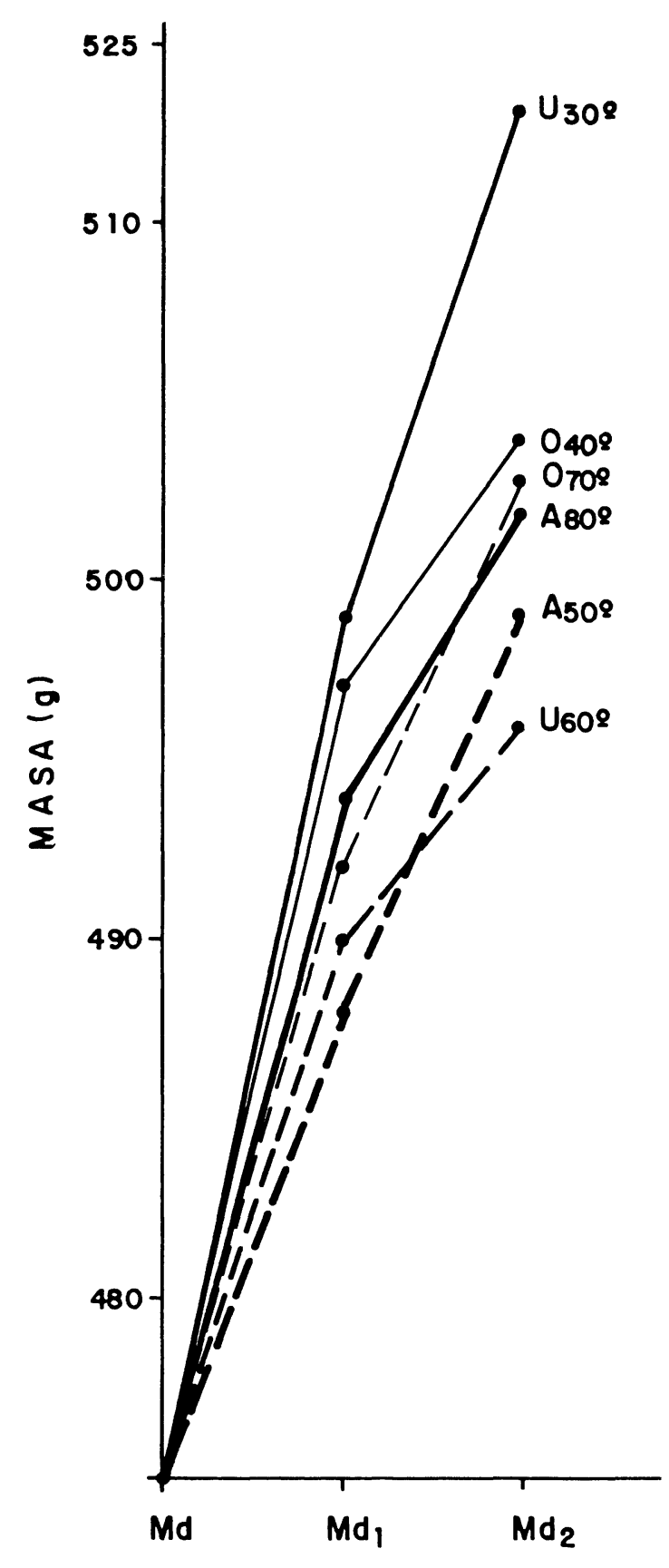

Fig. 6

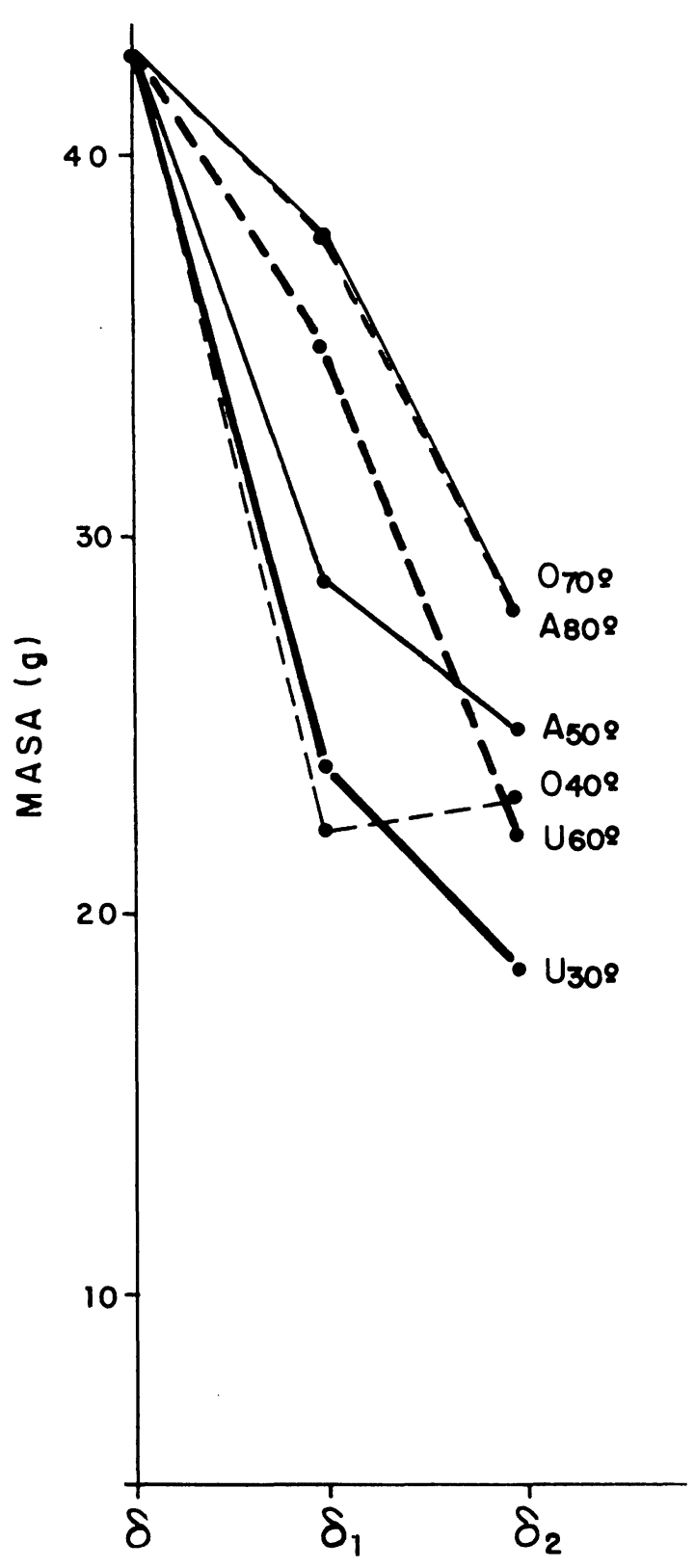

Fig. 7 


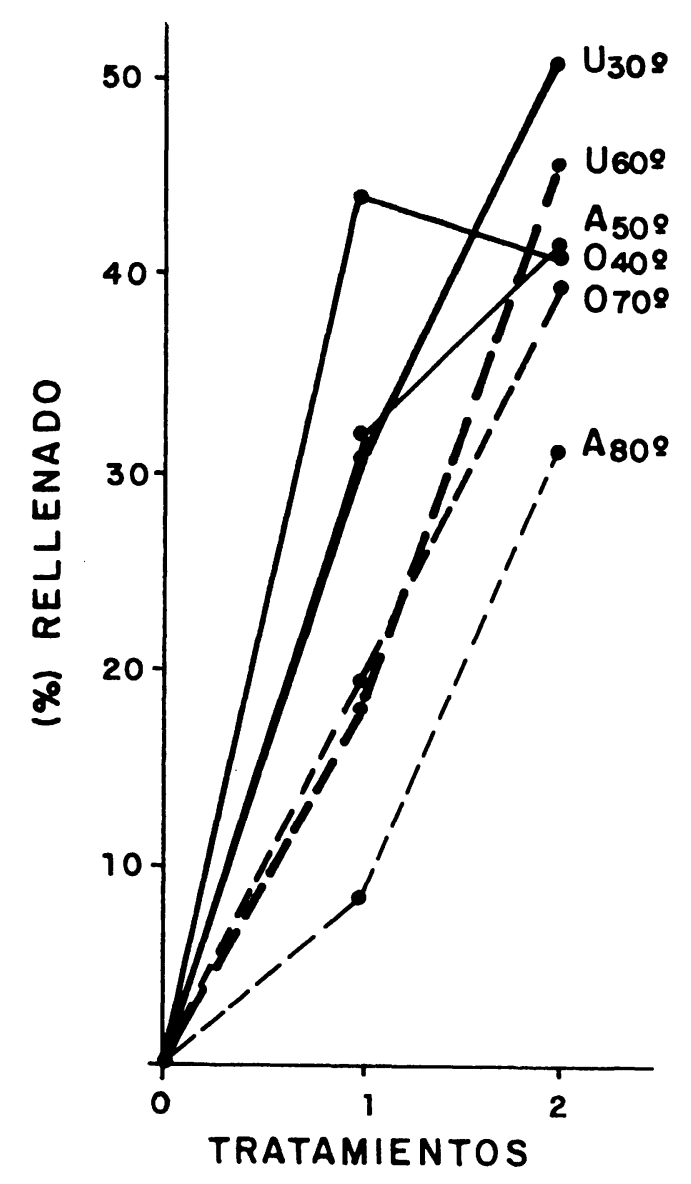

Fig. 8

\section{DISCUSIÓN DE RESULTADOS}

De la figura 1 se deduce el tiempo necesario para conseguir constancia en la pesada en función de las temperaturas, y así tenemos:

- A $20^{\circ} \mathrm{C}$, la probeta tarda en desecarse unos 12 días.

- A $30^{\circ} \mathrm{C}$, la probeta se deseca a los 10 días.

- A $40^{\circ} \mathrm{C}$ se termina el proceso de desecación a los 8 días.

- A partir de los $50^{\circ} \mathrm{C}$ se desecan a los 4 días, disminuyendo a 3 días a la temperatura de $80^{\circ} \mathrm{C}$.

Las masas desecadas varían también con la temperatura, es decir, queda agua retenida en las probetas y la desecación no es total a $20^{\circ} \mathrm{C}$, quedando aún pequeñas cantidades de la misma a $30^{\circ} \mathrm{C}$ y $40^{\circ} \mathrm{C}$ y estabilizándose las masas a partir de los $50^{\circ} \mathrm{C}$.

\section{RESULTS}

From Fig. 1 we make out the necessary time to obtain constant weight in function with the temperatures. In this way we have:

- At $20^{\circ} \mathrm{C}$, the test piece takes 12 days to desiccate.

- At $30^{\circ} \mathrm{C}$, the test piece takes 10 days to desiccate.

- At $40^{\circ} \mathrm{C}$, the test piece takes 8 days to desiccate.

- At $50^{\circ} \mathrm{C}$, onwards they take 4 days to desiccate, going down to 3 days at the temperature of $80^{\circ} \mathrm{C}$.

The desiccated bulks changes according to the temperature which means that water is retained in the test pieces and the desiccation is not completed at $20^{\circ} \mathrm{C}$, remaining small quantities at $30^{\circ} \mathrm{C}$ and $40^{\circ} \mathrm{C}$ and stabilizing from $50^{\circ} \mathrm{C}$ onwards. 


\section{CONCLUSIONES}

1. La masa de las probetas, y por consiguiente el rellenado de poros, aumenta al disminuir la temperatura de secado.

2. Con el par de sales, nitrato cálcico-oxalato sódico la óptima colmatación se alcanza con un solo tratamiento.

\section{CONCLUSIONS}

1. The bulk of the test pieces and also the refilling of the pores increases when the desiccation temperature decreases.

2. With the pair of salts, calcium nitrate-sodium oxalate, the best filling is reached with one treatment.

\section{BIBLIOGRAFÍA (BIBLIOGRAPHY)}

(1) S. E. PIHLAJAVAARA, H. PARROLL: "On the correlation between permeability properties and strength of concrete". Cement and concrete research. Vol. 5, pp. 321-328. 1975.

(2) VINSLOW y DING LIU: "The pore structure of paste in concrete". Cement and concrete research. Vol. 20. pp. 227-235. 1990.

(3) ROBERT L. DAY y BRYAN K. MARSH: "Measurement of porosity in cement pates". Cement and concrete research. Vol. 18. pp. 63-73. 1988.

(4) SCHÄFER, A.: Frostwiderstand un Porengefüge des Betons Beziehumgen und Prüfverfahren. Diss. Tu Clausthal. 1964.

(5) BLUMEL, O. W.; FREY, H.: Sättigungsbeiwert/und Frostwiderstands Von Zément Mörtel". Betonstein-Ztg. 34, n. ${ }^{\circledR} 12$. pp. 616618. 1968

(6) R. GERARD: "Determinación de la resistencia al hielo de los materiales de construcción mediante porometría de mercurio". C.T.S.C. 1.8969 Enero/Febrero 1969.

(7) P. G. de PAREDES G.: Monografía n. 232.1 .8963 . I.E.T.c.c.

(8) Normas UNE y manuales del I.E.T.c.C.

(9) N. SETTER and D. M. ROY: Cement and concrete research. Vol. 8, 623-634, 1978

(10) P. CATHARIN: Zement und Beton and concrete research 21, 98-105, 1976.

(11) W. CZERNIN: Zementchemie Für Baningenienre, Bauverlang Gmbh. 1977.

(12) G. D. de HAAS, P. C. KREISGER: Cement and concrete research, vol. 5, pp. 295-319. 1975

(13) H. UCHIKAWA, S. UCHIDA, S. HANEHARA: II cemento 67/90. 1991.

(14) P. S. DAWAELE y R. DAYL: Cement and concrete research 21, n. ${ }^{2} 4$, pp. 441-454. 1991.

(15) F. ARREDONDO: Materiales de construcción. I.E.T.C.c., 1976. 